\title{
New electrodes for determination of Clopidogrel- bisulphate
}

\author{
Omed Esmayl Haydar $^{1}$, Ali Ibraheem Khaleel ${ }^{2}$ \\ 1.Chemistry department, College of Science, University of Sulay manya \\ 2. Chemistry department, College of Science, University of Tikrit - Iraq
}

\section{Abstract}

In this research, new coated carbon electrodes were constructed and used for the determination of Clopidogrel drug The electrodes were constructed by preparing ion-pair for $(\mathrm{ClO})$ with Silicotungstic acid (STA) using di butyl phthalate (DBP) and tri Butylphosphate as a Binderr. These electrodes showed good sensitivity towards $\mathrm{ClO}$ with linear range of $\left(1.0 \times 10^{-7}-1.0 \times 10^{-3}\right) \mathrm{M}$ for both, correlation coefficient, (0.9693 and 0.9881$)$ for DBP and TBP respectively, the life time (25 and 23) days, optimum temperature range $(25-55)^{\circ} \mathrm{C}$ and optimum $\mathrm{pH}$ range (1.4-3.7) for both electrodes , limit of detection $\left(3.33 \times 10^{-8}\right.$ and $\left.2.63 \times 10^{-8}\right) \mathrm{M}$, slope (30.19 and 24.08) $\mathrm{mV} /$ decade for CLO-AST DBP and TBP electrodes respectively. These electrodes were successfully applied for determination of CLO in pure and pharmaceutical preparation form (tablets) with recovery of $99.42,99.03 \%$ for DBP and TBP respectivlly and Biological sample (Uria recovery of $99.47,99.24 \%$ and serim with recovery of $99.26,98.72 \%$. for both DBP, TBP

Key words: Coated wire electrode, Clopidogrel drug, Potentiometry, nanosilicate

\section{Introduction}

Clopidogrel bisulfate is a trademark prescription medicine used to treat people who have any of the following: A heart attack, a Stroke or Recent Stroke, chest pain due to heart problems, poor circulation in their legs (peripheral arterial disease), acute Coronary Syndrome (ACS), established Peripheral Arterial Disease; use with Proton Pump Inhibitors (PPI), clopidogrel reduces the risk of heart attack and stro ke in people who have cardiovascular disease [1- 4]. 
Clopidogrel hydrogen sulfate, methyl (+)-(S)-(ochlorophenyl)- 6,7-dihydrothieno[3,2-c]pyridin-5(4H)acetate hydrogensulfate, is a novel thienopyridine derivative that irreversibly blocks adenosine diphosphate (ADP) and is important in platelet aggregation, the cross-linking of platelets by fibrin. Clopidogrel (Fig. 1) is chemically related to Ticlopidine with superior side effects profile and dosing requirements [5- 7].

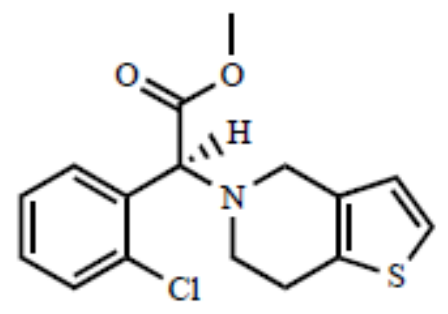

Fig. (1). Structural formula of clopidogrel

The empirical formula of clopidogrel bisulfate is $\mathrm{C}_{16} \mathrm{H}_{16} \mathrm{ClNO}_{2} \mathrm{~S} \cdot \mathrm{H}_{2} \mathrm{SO}_{4}$ and its molecular weight is 419.9 [8]. The molecule of clopidogrel contains an asymmetrical carbon leading to the existence of two enantiomers ( $\mathrm{R}$ and $\mathrm{S})[9,10]$. Clopidogrel free base was unstable due to a labile proton in the chiral center and was susceptible to racemization and hydrolysis of methyl ester group [11, 12].

Different analytical methods for the determination of clopidogrel were used such as spectrophotometric [11- 16] techniques, gas chromatography-mass spectrometry (GC-MS) [17], liquid chromatography-mass spectrometry (LC-MS) [18,19], HPLC-ESI-MS/MS, [20] RHPLC with UV detection [21-25], HPTLC $[26,27]$, Furthermore, the determination of clopidogrel and its impurities by capillary electrophoresis was reported.[28-30] and also by voltammetry [31].

This work describes the fabrication, construction with sensor potentiometric characterization, and application of a novel clopidogrel chemically modified PVC Silicon Oxide nanoparticles (CLO-NSiOPs) using clopidogrel-silicotungstate (CLO-STA).

\section{Reagents and mate rials}

All chemicals were of analytical reagent grade. Distilled water was used for the preparation of stock solutions. The following materials: CLO (India-) Poly vinyl ch loride (PVC) high molecular weight (Fluka), Di butyl phthalate (Sigma ,Germany), Tetra hydro furan.(THF) (Aldrich, USA). Silicotungstic acid (Merck, Germany) were used in this work. A stock solution of $0.01 \mathrm{M}$ of $\mathrm{ClO}$ drug was prepared by 
dissolving $4.199 \mathrm{~g}$ in $100 \mathrm{ml}$ distilled water. Dilute solutions $\left(1 \times 10^{-9}\right.$ to $\left.1 \times 10^{-3}\right) \mathrm{M}$ of drug were prepared by appropriate dilution with distilled water.

\section{Apparatus}

Potentiometric measurements were performed using HANNA instruments $301 \mathrm{pH}$ meter, Jenway3345 pH meter , calomel electrodes (RE-2BH). For elemental analysis CHN ElementarIsoprime100-Germany was used.

\section{Sample preparation}

Fourteen tablets of the Plavineer $(75 \mathrm{mg} /$ tablet) were finely powdered, the average weight of tablets is $(3.832 \mathrm{~g})$ and the weight of $(1.5324 \mathrm{~g})$ of this tablet powder(equivalent to0.4199g CLO) was dissolved in $100 \mathrm{ml}$ distilled water. And ten tablets of Plavineer $(75 \mathrm{mg} / \mathrm{tablet})$ were finely powdered(the average weights oftablets is $2.5656 \mathrm{~g}$ ).An accurate weight amount $1.4363 \mathrm{gof}$ this powder(equivalent to $0.4199 \mathrm{~g}$ CLO)was dissolved in $100 \mathrm{ml}$ distilled water ,Seven tablets of Clopidogrel Film-coated (75 mg/ tablet) were finely powdered(the average weight of tablets $1.9583 \mathrm{~g}$ ) an accurate weight of a mount $1.5662 \mathrm{~g}$ of this powder( equivalent to $0.4199 \mathrm{~g}$ CLO)was dissolved in $100 \mathrm{ml}$ distilled water. These three tablet solutions were filtered and to obtain $1.0 \times 10^{-2} \mathrm{~mol} / 1 \mathrm{CLO}$ solution. The working solutions in the range of $1.0 \times 10^{-7}$ $1.5 \times 10^{-2} \mathrm{~mol} / \mathrm{l}$ were prepared by dilutions using distilled water.

\section{Stock Solutions of Inte rfe ring Ions:}

Solutions of $1.0 \times 10^{-3} \mathrm{~mol} \mathrm{~L} \mathrm{~L}^{-1}$ for each of $\mathrm{NaCl}, \mathrm{KCl}, \mathrm{BaCl}_{2}, \mathrm{MgCl}_{2}, \mathrm{MnCl}_{2}, \mathrm{CrCl}_{3}, \mathrm{FeCl}_{3}, \mathrm{NH}_{4} \mathrm{Cl}, \mathrm{CuCl}_{2}$, $\mathrm{ZnCl}_{2}, \mathrm{NiCl}_{2}, \mathrm{CoCl}_{2}$, Tartarate, Glucose , D(-)Fructose , Lactose, Uric acid, Ascorbic acid, Aspirin were prepared by dissolving appropriate amount of these materials in distilled water in $50 \mathrm{ml}$ volumetric flasks.

\section{Preparation of ion-pairs}

The ion-pair was prepared by mixing $50 \mathrm{~mL}$ of equimolar of $1.0 \times 10^{-2} \mathrm{M}$ CLO to $50 \mathrm{~mL}$ of STA a white precipitate of CLO-STA was formed. The precipitate was filtered through Whatman filter paper 
(No. 42), and washed several times with distilled water. The precipitate was left for $24 \mathrm{~h}$ to dry at room temperature.

\section{Pre paration of modified coated wire sensor:}

Copper wire of $10 \mathrm{~cm}$ length and $1.0 \mathrm{~mm}$ diameter insulated by tight polyethylene tubes leaving $0.5 \mathrm{~cm}$ at one end for connection and at the other end $1 \mathrm{~cm}$ for coating. The coating mixture was prepared by dissolving $0.01 \mathrm{~g}$ ion pair (CLO-STA) in the minimum possible amount of tetra hydrofuran (2-3 ml) with $0.19 \mathrm{~g}$ powdered PVC and $0.35 \mathrm{ml}$ of TBP or DBP as plasticizer and $0.01 \mathrm{~g}$ of Nanosilica particles was added. Before coating the polished surface of the copper wire was washed with $\mathrm{HNO}_{3}$ followed by distilled water, and dried with acetone. the polished surface of the wire was coated with the active membrane by dipping ( $1 \mathrm{~cm}$ for coating) of this end into the coating solution then the film left for about 3 minutesfor dryness. The process was repeated for eighttimes. The prepared CWE were soaked in $1 \times 10^{-3} \mathrm{M}$ solution of the CLO for $24 \mathrm{~h}$.

\section{Results and Discussion:-}

CLO-STA as an electro active compound was used to prepare new sensors. Elemental analysis was carried out to confirm the composition of the ion-pair (CLO-STA) The obtained result revealed 9:1 composition for [CLO:STA] ion pair as indicated in( table 1)

(Table 1): Elemental analysis of the (CLO-STA) ion pair

\begin{tabular}{|c|c|c|c|c|c|c|}
\hline Sample & Color & Formula & & $\% \mathrm{C}$ & $\% \mathrm{H}$ & $\% \mathrm{~N}$ \\
\hline \multirow[t]{2}{*}{$(\mathrm{CLO})_{9} \mathrm{STA}$} & \multirow[t]{2}{*}{ white } & \multirow{2}{*}{$\begin{array}{l}{\left[\mathrm{C}_{16} \mathrm{H}_{16} \mathrm{O}_{3} \mathrm{SN}\right]_{9}} \\
{\left[\mathrm{H}_{4} \mathrm{SiW}_{12} \mathrm{O}_{40}\right] .2 \mathrm{H}_{2} \mathrm{O}}\end{array}$} & found & 28.19 & 2.45 & 2.059 \\
\hline & & & Calculate & 28.134 & 2.47 & 2.051 \\
\hline
\end{tabular}



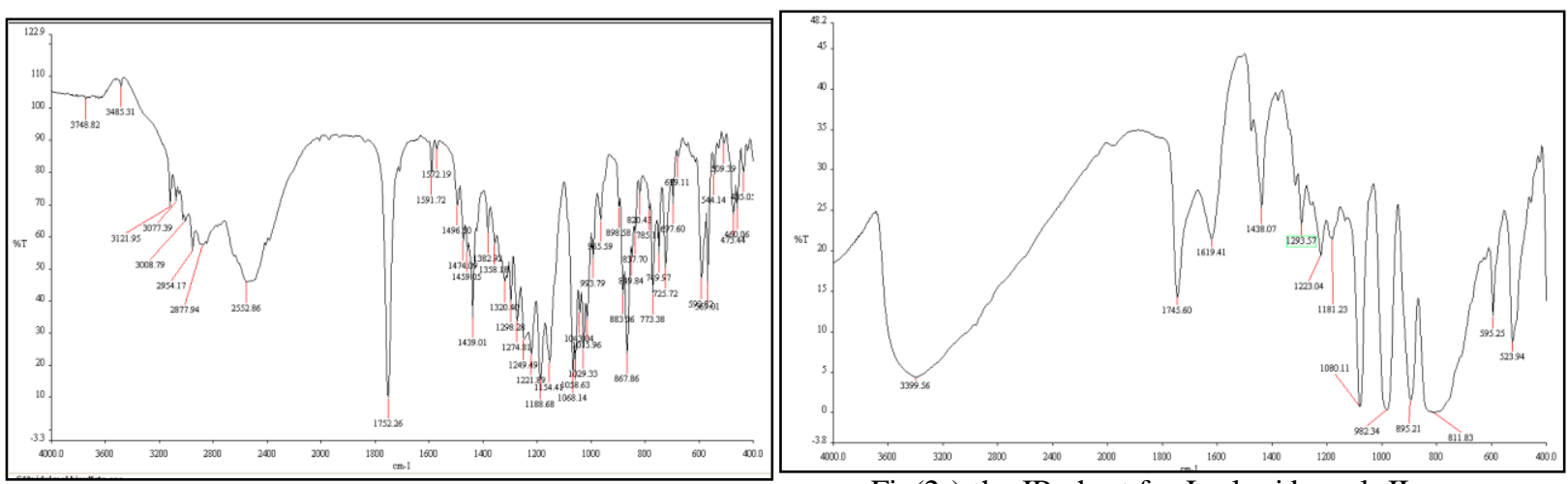

Fig(2 ) the IR chart for I- clopidogrel ,II-

clopidogrel - tungstosilicic acid haydrate

The IR Spectrum of pure CLO , the peaks at $(2954,2877,2552,1752,1188) \mathrm{cm}^{-1}$ are assigned for $\left(-\mathrm{CH}_{2}\right.$, $-\mathrm{CH}_{3}, \mathrm{C}-\mathrm{S}-\mathrm{C}, \mathrm{C}=\mathrm{O}$ ester, $\mathrm{C}-\mathrm{O}$ ester) respectively .

In the Spectrum of $(\mathrm{CLO})_{9}$ STA ion pair , the pecks at $(1745,1619,1080)$ are assigned for $(\mathrm{C}=\mathrm{O}$

carboxylic, $\mathrm{C}=\mathrm{C}, \mathrm{C}-\mathrm{O}$ ester) respectively . The disappearance of $(\mathrm{C}=\mathrm{O}, \mathrm{C}-\mathrm{O}$ ester and $\mathrm{C}-\mathrm{S}-\mathrm{C})$ is attributed to the occurrence of hydrogen bonding which is assured by the broad band at $3399 \mathrm{~cm}^{-1}$ in figure (2).

\section{The Effect of B inder :-}

The influence of the binder type on the characteristics of the studied sensors was investigated by using two binders of different polarities (DBP and TBP) and the results of this study are shown in ( table 2 ).

Table (2 ) Slope and $\mathrm{R}^{2}$ values for the calibration curves for NSiOS with different binders at $25.0{ }^{\circ} \mathrm{C}$.

\begin{tabular}{|l|l|l|}
\hline & DBP & TBP \\
\hline Slope & 30.19 & 24.08 \\
\hline $\mathrm{R}^{2}$ & 0.9693 & 0.9884 \\
\hline \multicolumn{2}{|l|}{ (NSiOS) range $\left(10^{-7}-10^{-3}\right) \mathrm{M}$} \\
\hline
\end{tabular}


The sensor with DBP as a solvent mediator gives the best response for pure drug and the best sensors are found to be in DBP binder because the slop of calibration is beter.

\section{Reproducibility of the Sensors}

The results of the two modified sensors NSiOS is compared with coated wire sensorCWS . The repeatability of the sensor response was examined by measurements in the range $1.0 \times 10^{-7}-1.0 \times 10^{-}$

${ }^{3}$ M CLO solution in DBP and TBP binder and the SD for 5 replicate for, NSiOS electrode measurements of emf was found to be $(1.088,0.95))$ for DBP and TBP binder respectively.

\section{Res ponse Time and Life Time}

The dynamic response time of sensor was tested by measuring the time required to achieve a steady-state potential (within $\pm 1 \mathrm{mV}$ ) after successive immersions of the sensor in a series of drug solutions, each having a 10 -fold increase in concentration from $1.0 \times 10^{-7}-1.0 \times 10^{-3} \mathrm{M}$. When the sensor was transferred from one concentration solution to another one, it was stabilized to a value higher (17s) than its value, which may be due to the memory effect. Steady potential within of (17 and 25) s for NSIO sensors forDBP and TBP respectivly show in (table 2).

The life time is (25,23) day for NSiOS sensors in (DBP and TBP) binder (table3).

Table(3 ) Electrochemical response Characteristics of NSiOS in DBP and TBP.

\begin{tabular}{|l|c|c|}
\hline \multirow{2}{*}{ Parameter } & DBP & TBP \\
\cline { 2 - 3 } & NSiOS & NSiOS \\
\hline Slope $\left(\mathbf{m V ~ d e c a d e ~}^{\mathbf{1}}\right)$ & 30.19 & 24.08 \\
\hline Intercept & 256.231 & 218.6 \\
\hline Correlation Coefficient $\mathbf{R}^{\mathbf{2}}$ & 0.9693 & 0.9881 \\
\hline
\end{tabular}




\begin{tabular}{|l|c|c|}
\hline Linear range (mol./L) & $10^{-7}-10^{-3}$ & $10^{-7}-10^{-3}$ \\
\hline limit of detection ( M ) & $3.33 \times 10^{-8}$ & $2.63 \times 10^{-8}$ \\
\hline Response time for S & 25 & 17 \\
\hline Working pH range & $1.4-3.7$ & $1.4-3.7$ \\
\hline Life time, day & 25 & 23 \\
\hline Temperature ${ }^{\circ} \mathbf{C}$ & $25-55$ & $25-55$ \\
\hline Accuracy (\% recovery ) & $99.42 \pm 1.088$ & $99.03 \pm 0.95$ \\
\hline
\end{tabular}

\section{Calibration plot of the fabricated electrodes and limit of detection}

The fabricated electrodes (NSiOS-DBP) and (NSiOS-TBP) were immersed along with Calomel reference electrode in solutions of CLO in the concentration range $\left(1 \times 10^{-8}-1 \times 10^{-2}\right) \mathrm{M}$. The $\mathrm{E}(\mathrm{mV})$ against $-\log$ [CLO] was plotted as shown in figure3. Both electrodes show a linear response over the concentration ranges from $\left(1 \times 10^{-7}-1 \times 10^{-3}\right) \mathrm{M}$ with near Nernstian slopes of and $(30.19$ and 24.08$) \mathrm{mV} / \mathrm{decade}$ for (NSiOS-DBP) and (NSiOS-TBP), and values of LOD $\left(3.33 \times 10^{-8}\right.$ and $\left.2.63 \times 10^{-8}\right)$ for (NSiOS-DBP) and (NSiOS-TBP) electrodes respectively indicating that the sensors under investigation are highly sensitive which can be applied for determination of trace amounts of CLO drug it shown in (table 3).

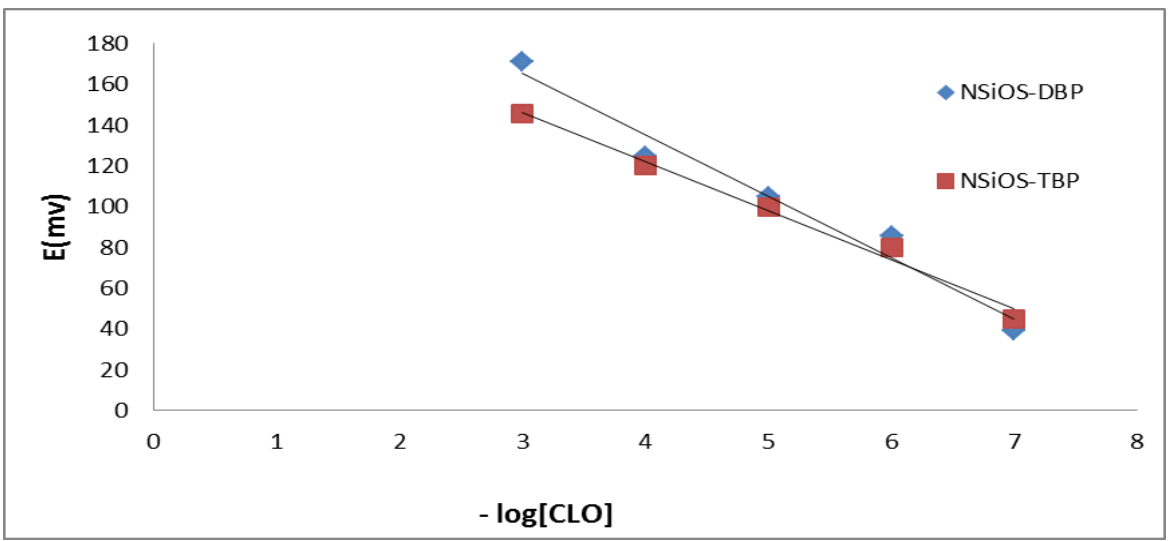

Figure (3): Standard curve of CLO using new (NSiOS-DBP) and (NSiOS-TBP) electrodes. 


\section{Effect of pH}

The effect of $\mathrm{pH}$ on the performance of the two electrodes was investigated using concentration of $\left(1.0 \times 10^{-4}\right) \mathrm{M}$ of CLO drug at different $\mathrm{pH}$ values (1-10.5). The $\mathrm{pH}$ value was adjusted by addition of s mall volumes of $\mathrm{HCl}$ and/or $\mathrm{NaOH}$ solution (0.1-1 $\mathrm{M}$ of each). The potential at each $\mathrm{pH}$ value was recorded. It is obvious (fig 4) that the best $\mathrm{pH}$ range is from (1.4-3.7) for both electrodes where the potential is independent on $\mathrm{pH}$. However the potential decreases gradually at $\mathrm{pH}$ values higher than 3.7 for (NSiOSDBP) and (NSiOS-TBP) it shown in (table 3) and (figure 4).

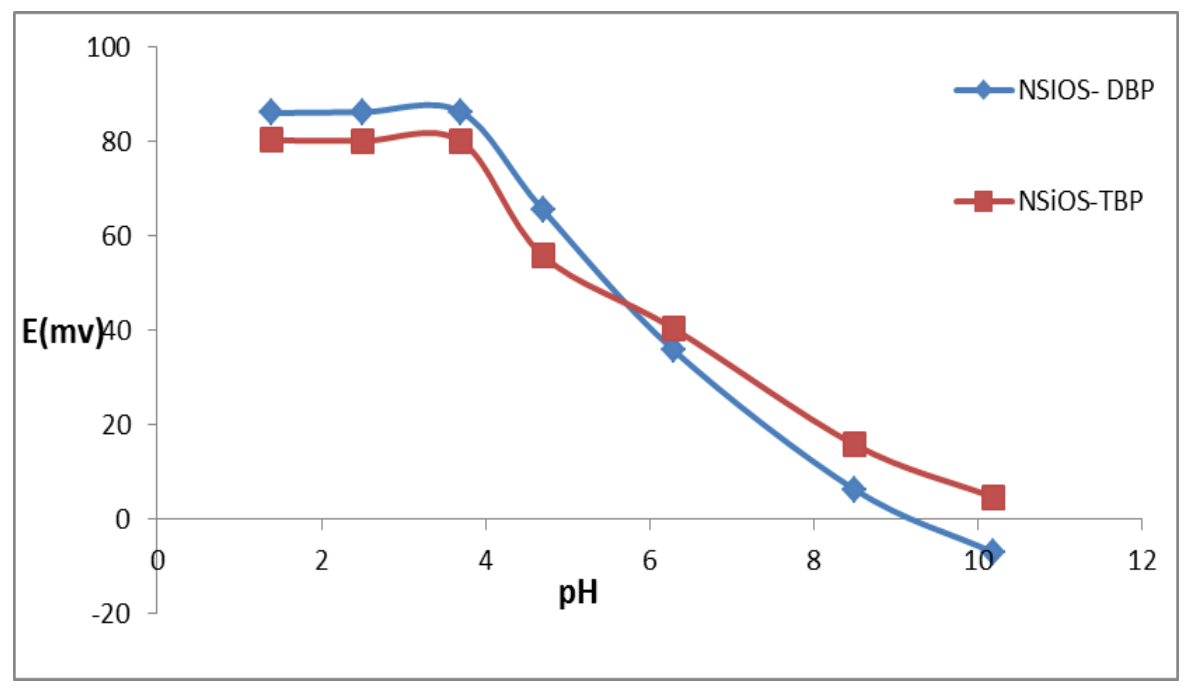

Figure (4): Effect of $\mathrm{pH}$ on the response of NSiOS-DBP and NSiOS-TBP electrodes $\quad$ using CLO solution $\left(1 \times 10^{-4}\right) \mathrm{M}$

\section{Selectivity of the studied sensors}

The selectivity coefficients (log K) of the studied sensors were determined applying separate solution method (SSM) [32, 33]. In SSM, the potential of cell comprising the new constructed electrode and a reference electrode is measured in two separate solutions, where (CLO) and (interfering ion or compound) are at the same activity. Selectivity coefficients were calculated using Nicolsky equation [32] :

$$
\log \mathrm{K}=(\mathbf{E j}-\mathbf{E i}) / \mathbf{S}
$$


where $\mathrm{Ei}$ is the potential measured in $\left(1 \times 10^{-3}\right) \mathrm{mol} / \mathrm{L} \mathrm{CLO}, \mathrm{Ej}$ the potential measured in $1 \times 10^{-3} \mathrm{~mol} / \mathrm{L}$ of the interfering ion or compound, $\mathrm{S}$ is the slope of the calibration plot. The $\mathrm{K}$ value represents the difference in potential in the presence of interfering ion (j) and when (j) is not present. When the value is less than 1 this indicates that the electrode shows low response to the interfering ions. The results of selectivity are shown on table (4). The K values shows a very high selectivity of the electrodes towards the CLO.

Table (4): K value of both NSiOS-DBP and NSiOS-TBP electrodes

\begin{tabular}{|c|c|c|}
\hline Interfering ion & $\mathrm{K}$ & \\
\hline or compound & NSiOS-DBP & NSiOS-TBP \\
\hline $\mathbf{K}^{+}$ & $4.51 \times 10^{-5}$ & $4.42 \times 10^{-3}$ \\
\hline $\mathrm{Na}^{+}$ & $3.82 \times 10^{-3}$ & $3.52 \times 10^{-3}$ \\
\hline $\mathrm{NH}_{4}{ }^{+}$ & $3.95 \times 10^{-5}$ & $3.75 \times 10^{-5}$ \\
\hline $\mathrm{Ba}^{2+}$ & $3.34 \times 10^{-3}$ & $3.12 \times 10^{-3}$ \\
\hline $\mathrm{Cu}^{2+}$ & $4.13 \times 10^{-3}$ & $4.13 \times 10^{-3}$ \\
\hline $\mathrm{Co}^{2+}$ & $2.10 \times 10^{-3}$ & $2.40 \times 10^{-3}$ \\
\hline $\mathrm{Ni}^{2+}$ & $3.34 \times 10^{-3}$ & $3.55 \times 10^{-3}$ \\
\hline $\mathbf{M n}^{2+}$ & $2.12 \times 10^{-3}$ & $2.02 \times 10^{-3}$ \\
\hline $\mathbf{M g}^{2+}$ & $3.32 \times 10^{-3}$ & $3.01 \times 10^{-3}$ \\
\hline $\mathbf{Z n}^{2+}$ & $1.95 \times 10^{-5}$ & $1.63 \times 10^{-5}$ \\
\hline $\mathrm{Fe}^{3+}$ & $2.14 \times 10^{-2}$ & $2.01 \times 10^{-2}$ \\
\hline $\mathrm{Cr}^{3+}$ & $4.30 \times 10^{-3}$ & $4.12 \times 10^{-3}$ \\
\hline Tartrate & $3.18 \times 10^{-2}$ & $3.23 \times 10^{-2}$ \\
\hline D- Fructose & $2.51 \times 10^{-5}$ & $2.31 \times 10^{-3}$ \\
\hline
\end{tabular}




\begin{tabular}{|l|l|l|}
\hline Glucose & $4.52 \times 10^{-3}$ & $4.42 \times 10^{-3}$ \\
\hline Lactose & $3.43 \times 10^{-2}$ & $3.61 \times 10^{-2}$ \\
\hline Uric acid & $3.34 \times 10^{-2}$ & $3.66 \times 10^{-2}$ \\
\hline Ascorbic acid & $3.33 \times 10^{-2}$ & $3.43 \times 10^{-2}$ \\
\hline Aspirin & $2.21 \times 10^{-2}$ & $2.00 \times 10^{-2}$ \\
\hline
\end{tabular}

\section{Precision and Accuracy}

To evaluate the accuracy and precision of the proposed method, pure and pharmaceutical drug solutions at different levels (within the working limits) was analyzed, each solution was repeated for (5) times. Precision and accuracy were based on the calculated percent relative standard deviation (RSD\%) and percent relative error $(\mathrm{RE} \%)$. The value of RE\% is not more than $(-0.97)$ and value or RSD\% is not more than (1.56) . The results (table 6) show that these methods have reasonable precision and accuracy.

\section{Robustness and Ruggedness}

The robustness method of the NSiOS was examined by changing the aqueous solution to acetate buffer $\mathrm{pH}(4)$ and the percentages recovery were $99.2 \pm 1.8$ for the NSiOS in DBP binder and $98.6 \pm 1.45$ in the TBP binder .

The ruggedness or the reproducibility was checked by using another model of pH-meter (Hanna ) and different calomel (Jenway) electrode. was presented by the results obtained as percentage recovery was $99.0 \pm 1.3$ for the NSiOS in DBP binder and $.9,99.2 \pm 1.6$ in TBP binder for Hanna instrument but when we using Jenway reference electrode the recovery are $99.4 \pm 1.9$ for the NSiOS in DBP binder and $98.2 \pm$ 1.3 for the NSiOS in TBP binder (table 5)

These results were closely in agreement with those obtained for standard drug solution, using new conditions for robustness and ruggedness tests (Table 6,Table 5). 
This is main two sensorgive accurate result when we change the instrument and medium .

(Table 5) The recovery \pm SD For robustness and ruggedness for NSiOs in TBP and DBP binder

\begin{tabular}{|l|l|l|}
\hline Parameter & NSiOS - TBP & NSiOS - DBP \\
\hline Robustness & $98.6 \pm 1.45$ & $99.2 \pm 1.8$ \\
\hline Ruggedness for (Hanna pH meter) & $99.2 \pm 1.6$ & $99.0 \pm 1.3$ \\
\hline Ruggedness for (Jenway calomel reference electrode) & $98.2 \pm 1.3$ & $99.4 \pm 1.9$ \\
\hline
\end{tabular}

\section{Analytical Applications:}

CLO was determined using a direct calibration method for both pure and pharmaceutical forms. The results were calculated as the recoveries \% using the prepared electrodes (NSiOS-DBP) and (NSiOSTBP). The percentage recoveries for determination of CLO pure drug solutions are (99.19 and 99.03) for (NSiOS-DBP and NSiOS-TBP) electrodes respectively. The percentage recoveries for determination of CLO tablets (Plavinerr $75 \mathrm{mg}$ tablet) are (99.42 and 99.48) and for (Plagerine $75 \mathrm{mg}$ tablet) are (99.89 and 99.1) but for (Clopidogrel $75 \mathrm{mg}$ tablet) are (99.98 and 99.44) for (NSiOS-DBP and NSiOS-TBP) electrodes respectively shown in ( table 6). 
Table (6) Statistical treatment of data for determinations of CLO in pure and npharmaceutical preparations using new (NSiOS-DBP) and (NSiOS-TBP) electrodes

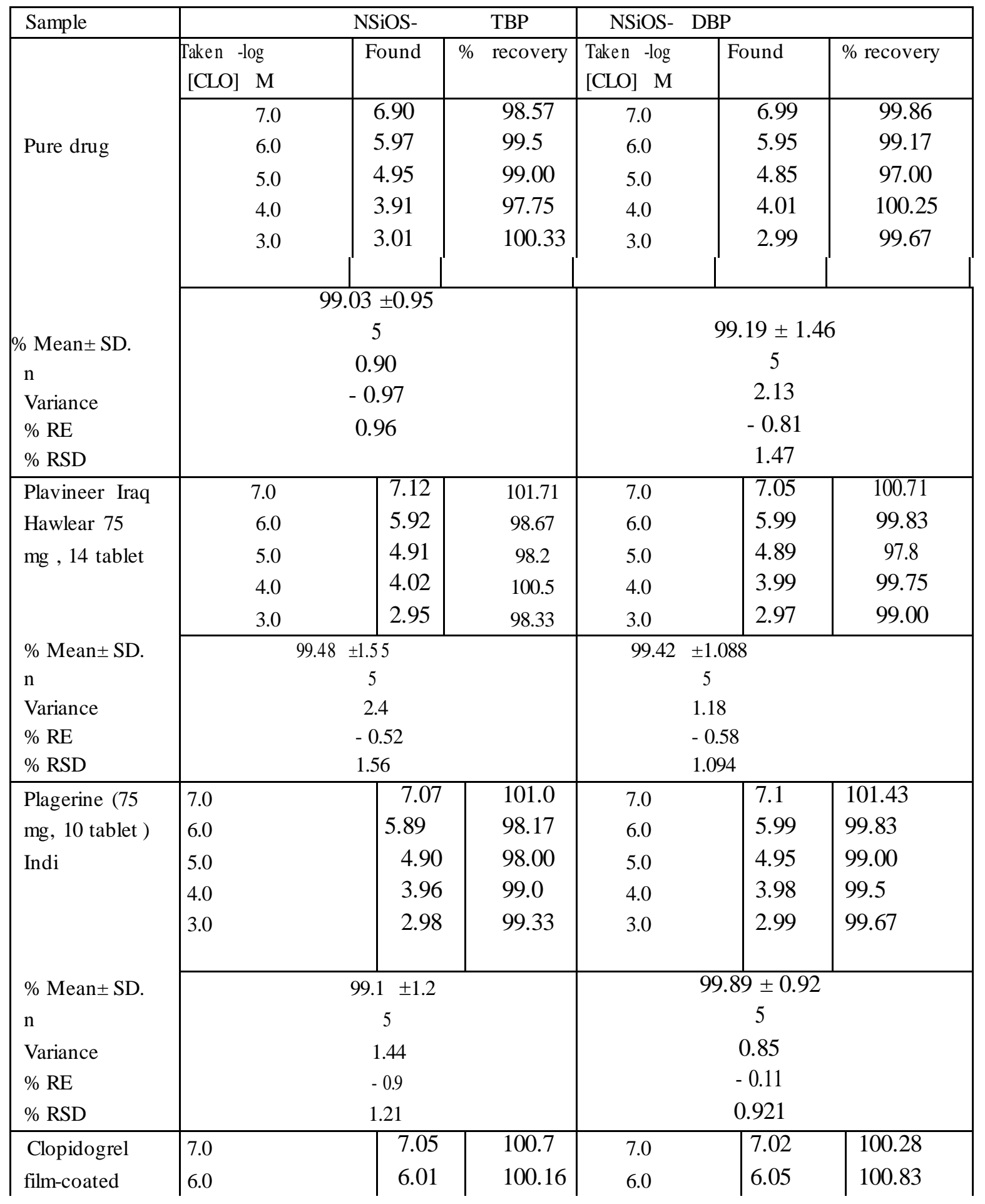




\begin{tabular}{|c|c|c|c|c|c|c|}
\hline Tablet (75mg, & 5.0 & 4.93 & 98.60 & 5.0 & 4.99 & 99.80 \\
\hline 7 tablet), UK & 4.0 & 3.95 & 98.75 & 4.0 & 3.98 & 99.50 \\
\hline & 3.0 & 2.97 & 99.00 & 3.0 & 2.985 & 99.50 \\
\hline$\%$ Mean \pm SD. & \multicolumn{3}{|c|}{$99.44 \pm 0.93$} & \multicolumn{3}{|c|}{$99.98 \pm 0.57$} \\
\hline $\mathrm{n}$ & \multicolumn{3}{|c|}{5} & \multicolumn{3}{|c|}{5} \\
\hline Variance & \multicolumn{3}{|c|}{0.86} & \multicolumn{3}{|c|}{0.32} \\
\hline$\% \mathrm{RE}$ & \multicolumn{3}{|c|}{-0.56} & \multicolumn{3}{|c|}{-0.02} \\
\hline$\%$ RSD & \multicolumn{3}{|c|}{0.93} & \multicolumn{3}{|c|}{0.57} \\
\hline
\end{tabular}

\section{Analytical Applications}

The standard addition, calibration curve and potentiometric titration methods were proved to be successfulfor the determination of CLO in its pure solutions, CLO tablets (75 mg/tablet table 6) and biological fluids (human serum and urine, table 7) using the NSiOS.

\section{Dete rmination of CLO in Human Se rum and Urine:}

The proposed GGOS, CWS and NSiOS methods were successfully applied to determine CLO in biological fluids and the obtained results are summarized in Table (7)

The determination of CLO in spiked human serum shows that a wide concentration range of the drug can be determined by the proposed sensors with high precision and accuracy.

In urine samples the standard addition method was applied to overcome the matrix effects in these samples. The sensors are washed by distilled water after each measurement to protect the sensor surface from sticking of biological components. In spiked urine and human serum the recovery was ranged from 99.47-99.26 (table 7) using DBP binder and 99.47- 99.26 for NSiOS show in (Table 7) using TBP binder.

Table (7) Statistical treatment of data obtained for determination CLO. in Human urine and serum using NSiOS ) - for both DBP and TBP binder

\begin{tabular}{|c|c|l|l|c|l|l|}
\hline Sample & \multicolumn{2}{|l|}{ NSiOS-TBP } & \multicolumn{3}{l|}{ NSiOS-DBP } \\
\hline & $\begin{array}{c}\text { Taken -log } \\
\text { [CLO] M }\end{array}$ & Found & $\begin{array}{l}\% \\
\text { recovery }\end{array}$ & $\begin{array}{l}\text { Taken -log } \\
\text { [CLO] M }\end{array}$ & Found & $\begin{array}{l}\% \\
\text { recovery }\end{array}$ \\
\cline { 2 - 7 } Human Urine & 7.0 & 7.03 & 100.43 & 7.0 & 7.02 & 100.29 \\
& 6.0 & 5.9 & 99.12 & 6.0 & 5.97 & 99.50 \\
& 5.0 & 4.95 & 99.606 & 5.0 & 4.99 & 99.80 \\
& 4.0 & 3.92 & 98.00 & 4.0 & 3.95 & 98.75 \\
& 3.0 & 2.99 & 99.67 & 3.0 & 2.97 & 99.00 \\
\hline
\end{tabular}




\begin{tabular}{|c|c|c|c|c|c|c|}
\hline $\begin{array}{l}\% \text { Mean } \pm \text { SD. } \\
\text { n } \\
\text { Variance } \\
\% \text { RE } \\
\% \text { RSD }\end{array}$ & \multicolumn{3}{|c|}{$\begin{array}{c}99.24 \pm 0.90 \\
5 \\
0.81 \\
-0.76 \\
0.91\end{array}$} & \multicolumn{3}{|c|}{$\begin{array}{c}99.47 \pm 1.51 \\
5 \\
2.28 \\
-0.53 \\
1.52\end{array}$} \\
\hline Human Serum & $\begin{array}{l}7.0 \\
6.0 \\
5.0 \\
4.0 \\
3.0\end{array}$ & $\begin{array}{l}6.89 \\
6.09 \\
4.87 \\
3.97 \\
2.91\end{array}$ & $\begin{array}{l}98.43 \\
101.50 \\
97.4 \\
99.25 \\
97.00\end{array}$ & $\begin{array}{l}7.0 \\
6.0 \\
5.0 \\
4.0 \\
3.0\end{array}$ & $\begin{array}{l}7.04 \\
5.96 \\
4.92 \\
3.96 \\
2.97\end{array}$ & $\begin{array}{l}100.57 \\
99.33 \\
98.4 \\
99.00 \\
99.00\end{array}$ \\
\hline $\begin{array}{l}\text { \% Mean } \pm \text { SD. } \\
\text { n } \\
\text { Variance } \\
\% \text { RE } \\
\% \text { RSD }\end{array}$ & \multicolumn{3}{|c|}{$\begin{array}{c}98.72 \pm 1.79 \\
5 \\
3.20 \\
-1.28 \\
1.81\end{array}$} & \multicolumn{3}{|c|}{$\begin{array}{c}99.26 \pm 1.40 \\
5 \\
1.27 \\
-0.74 \\
1.41\end{array}$} \\
\hline
\end{tabular}

\section{Conclusion}

The proposed method introduced an ion selective electrodes for the determination of CLO based on PVC matrix and (DBP and TBP) as a plasticizer and using STA as active materials These electrodes showed a successfulapplication with low limit of detection and good recovery. The electrodes also showed long life time, fast response time, good selectivity and reasonable working concentration ranges.

\section{REFERANCES}

1- Budavari S. The Merck Index. 13th Edtn, Merck \& Co, USA. 2011

2- Henein HW ATLAS 2 everything about drugs from A to Z. Nobar publisher, USA. 2006

3- Gomes Y, Adams E, Hoogmartens Analysis of purity in 19 drug product tablets containing clopidogrl: 18 copies versus the original brand. J Pharma Biomed Anal 2004, 34: 341-348.

4- Taubert D, Kastrati A, Gorchakova O, Lazar A, Von Beckerath N, et al., Pharmacokinetics of clopidogrel after administration of a high loading dose.ThrombHaemost 2004 ,92: 311-316.

5- Mills, D.C.; Puri, R.; Hu, C.J.; Minniti, C.; Grana, G.; Freedman, M.D.; Colman, R.F.; Colman, R.W . Clopidogrel inhibits the binding of ADP analogues to the receptor mediating inhibition of platelet adenylatecyclase. Arteriosc. Thromb. 1992, 12, 430-436

6- Majerus, P.W.; Tollefsen, D.M. Blood coagulation and anticoagulant, thrombolytic, and antiplatelet drugs, in: L.L. Brunton (Ed.), The Pharmacological Basis of Therapeutics, 11th edition, The McGrawHill Companies, New York, NY, 2006, p. 1483.

7- www.RXlist.com, PLAVIXTM, RxMed: Pharmaceutical Information, Sanofi/Bristol- Mayers Squibb http://www.fda.gov/medwatch/safety/2007/May PI/Plavix PI.pdf 
8- Savi, P.; Combalbert, J.; Gaich, C.; Rouchon, M.C.; Maffrand, J.P.; Berger, Y.; Herbert, J.M. The antiaggregating activity of clopidogrel is due to a metabolic activation by the hepatic cytochrome P4501A.. Thromb. Haemost. 1994, 72, 313-317.

9- Pereillo, J.M.; Maftouh, M.; Andrieu, A.; Uzabiaga, M.F.; Fedeli, O.; Savi, P.; Pascal, M.; Herbert, J.M.; Maffrand, J.P.; Picard, C. Structure and Stereochemistry of the Active Metabolite of Clopidogrel. Drug MetabolDispos.2002, 30(11), 1288-1295.

10- Gomez, Y.; Adams, E.; Hoogmartens, J. Analysis of purity in 19 drug product tablets containing clopidogrel: 18 copies versus the original brand. J. Pharm. Biomed. Anal., 2004, 34, 341-348.

11- Nayana P, Yogita S, Mahajan NS, Pore YV, Kuchekar BS, et al., Spectrophotometric estimation of clopidogrelbisulphate in pharmaceuticaldosage forms. Int J Chem Sci., 2009, 7: 216-218.

12- Game MD, Gabhane KB, Sakarkar DM, Quantitative analysis of clopidogrelbisulphate and as pirin by first derivative spectrophotometric method in tablets. Ind J Phama Sci., 2010, 72: 825-828.

13- Gurav S, Tembare R, Salunkhe V, Devprakash, A Spectrophotometric determination of clopidogrelbisulphate in pharmaceutical formulations. J.Pharma Tech Res., 2011, 1: 258-263.

14- Cholke PB, Ahmed R, Chemate SZ, Jadhave KR Development and validation of spectrophotometric method for clopidogrelbisulphate in pure and in film coated tablet dosage form. Arch AppliSci Res.,2012 4: 59-64.

15- Rujput SJ., George RK, Ruikar DB Chemometric simultaneous estimation of clopidogrelbisulphate and aspirin from combined dosage. IndJ.Pharma Sci.,2008, 70: 450-454.

16- Yazbi, F., Mahrous, M., Hammad, H., Sonji, G., et al,.Kinetic spectrophotometric determination of betaxolol, clopidogrel and imidapril in pharmaceutical. Anal. Techn., 2010, 6 (3), 228-236.

17- Lagorce P, Pere Y, Ortiz J, Necciari J, Bressolle F., Assay method for the carboxylic acid in human plasma by gas chromatography mass spectrometry. J .Chromatogr B Biomed Sci Appl., 1998, 720: (12)107-117.

18- Shin BS, Yoo SD Determination of clopidogrel in human plasma by liquid chromatography/tandem mass spectrometry: application to clinical pharmacokinetic study. Biomed Chromatogr ,2007, 21: 883889.

19- Takahashi M, Pang H, Kawabata K, Farid NA, Kurihara A Quantitative determination of clopidogrel active metabolite in human plasma by LC-MS/MS. J Pharm Biomed Anal.,2008. 48: 1219-1224.

20- Silvestro L, Gheorghe M, Iordachescu A, Ciuca V, Tudoroniu A, et al. Development and validation of an HPLC-MS/MS method to quantify clopidogrel acyl glucuronide, clopidogrel acid metabolite, and clopidogrel in plasma samples avoiding analyte back-conversion. Anal Bioanal Chem. (2011), 401: 1023-1034.

21- Shrivastava PK, Basniwal PK, Jain D, Shrivastava SK Concurrent estimation of clopidogrelbisulphate and aspirin in tablets by validated RPHPLC method. Indian J Pharm Sci 2008 70: 667-669.

22- Alarfaj NA, Stability-indicating liquid chromatography for determination of clopidogrelbisulphate in tablets: Application to content uniformity testing. J Saud ChemSocm. 2012, 16: 23-30.

23- Panda SS, Ion-pairing RP-HPLC method for simultaneous determination of aspirin and clopidogrelbisulphate in tablet and capsule dosage form. Int J Pharma Tech Res.2010, 22: 269-273.

24- Londhe SV, Deshmukh RS, Mulgund SV, Jain KS. Development and validation of a reversed-phase HPLC method for simultaneous determination of aspirin, atrovastatin calcium and clopidogrelbisulphate in capsules. IndPharmaSci .2011, 73: 23-29.

25- Sultana N, Ali AK, Arayne MS, Nawaz M. Simultaneous determination of clopidogrel and aspirin by RP-HPLC from bulk material and dosage formulations using multivariate calibration technique. $\mathrm{J}$ ChromatogrSci .2011, 49: 165-169. 
26- Petal RB, Shankar MB, Petal MR, Bhatt KK. Simultaneous estimation of acetylsalicylic and clopidogrelbisulphate in pure powder and tablet formulations by high performance column liquid chromatography and high-performance thinlayer chromatography. J AOAC Int : 2008, 91: 750-755.

27- Sinha PK, Damel MC, Bothara KG .A validated stability indicating HPTLC method for determination of aspirin and clopidogrelbisulphate in combined dosage form. J Anal Chem. 2009, 4: 152-160.

28- Fayed AS, Weshahy SA, Shehata MA, Hassan NY, Pauwels J, et al. Separation and determination of clopidogrel and its impurities by capillary electrophoresis. J Pharm Biomed Anal. 2009,49: 193-200.

29- Karaźniewicz-Łada M, Główka F, Oszkinis G . Capillary zone electrophoresis method for determination of (+)-S clopidogrel carboxylic acid metabolite in human plasma and urine designed for biopharmaceutic studies. J Chromatogr B AnalytTechnolBiomed Life Sci. 2010,878: 1013-1018.

30- Serra H, Bronze Mdo R, Simplício AL, Simultaneous determination of clopidogrel and its carboxylic acid metabolite by capillary electrophoresis. J Chromatogr B AnalytTechnolBiomed Life Sci. 2010,878: 1480-1486.

31- Dermis S, Aydogan E, Electrochemical study of the antiplatelet agent clopidogrel and its determination using differential pulse voltammetry in bulk form and pharmaceutical preparations with a glassy carbon sensor. Pharmazie. 2010, 65: 175-181.

32- Cosofret V.V., Buck R.P. ; "Pharmaceutical Applications of Membrane Sensors" , 1992,1, 50-284.

33- Vytras K. ; "Journal of Pharmaceutical and Biomedical Analysis " ,1989,7 ,789-812.

34- Moody G. J., Thomas J. D. R.; "Talanta" ,1972,19,623,.

35- Cosofert V.V., Nahir, T. M.; Lindner E., Buck R. R.; "J. Electro. Anal. Chem.", 1992,137, 327. 